\title{
Phloem sap intricacy and interplay with aphid feeding
}

\section{Complexité de la sève phloèmienne et impact sur l'alimentation des pucerons}

\author{
Sylvie Dinant ${ }^{\mathrm{a}, *}$, Jean-Louis Bonnemain ${ }^{\mathrm{b}}$, Christine Girousse ${ }^{\mathrm{c}}$, Julia Kehr ${ }^{\mathrm{d}}$ \\ a UMR 1318 INRA-AgToParisTech, institut Jean-Pierre-Bourgin, bâtiment 2, route de Saint-Cyr, 78000 Versailles, France \\ ' CNRS, service de physiologie moléculaire du transport des sucres chez les végétaux (FRE 3091), université de Poitiers, 40, avenue du recteur Pineau. \\ 86022 Poitiers cedex, France \\ 'INRA, UMR 1095, Genetics, Diversity and Ecopiysiology of Cereais, 234, avenue du Brézet, 63100 Clennont-Fentand, France \\ dentro de Biotecnología y Genómica de Plantas (CBGP), Campus de Montegancedo, 28223 Pozuelo de Alarcón, Madid, Spain
}

\section{ARTICLE INFO}

\section{Keywords:}

Stylectomy

Phloem exudation

Phloem sap

Sieve element

EPG

Transporters

Plant defence

\begin{abstract}
A B S T R A C T
Aphididae feed upon the plant sieve elements (SE), where they ingest sugars, nitrogen compounds and other nutrients. For ingestion, aphid stylets penetrate $S E$, and because of the high hydrostatic pressure in SE, phloem sap exudes out into the stylets. Severing stylets to sample phloem exudates (i.e. stylectomy) has been used extensively for the study of phloem contents. Alternative sampling techniques are spontaneous exudation upon wounding that only works in a few plant species, and the popular EDTA-facilitated exudation technique. These approaches have allowed fundamental advances on the understanding of phloem sap composition and sieve tube physiology, which are surveyed in this review. A more complete picture of metabolites, ions, proteins and RNAs present in phloem sap is now available, which has provided large evidence for the phloem role as a signalling network in addition to its primary role in partitioning of photo-assimilates. Thus, phloem sap sampling methods can have remarkable applications to analyse plant nutrition, physiology and defence responses. Since aphid behaviour is suspected to be affected by phloem sap quality, attempts to manipulate phloem sap content were recently undertaken based on deregulation in mutant plants of genes controlling amino acid or sugar content of phloem sap. This opens up new strategies to control aphid settlement on a plant host.
\end{abstract}

\section{R É S U M É}

Les Aphididae s'alimentent directement dans les éléments criblés du phloème, dans lesquels ils prélèvent la sève phloèmienne riche en sucres, composés azotés et autres nutriments essentiels à leur développement et reproduction. Pendant la phase d'ingestion, leurs pièces buccales (stylets) pénètrent dans les éléments criblés, et en réponse à la pression hydrostatique élevée dans les tubes criblés, la sève phloèmienne remonte dans les stylets. Le prélèvement de sève phloèmienne à partir des stylets sectionnés (stylectomie) a été largement utilisé pour l'étude de sa composition. D’autres techniques de prélèvements, telles que l'exsudation spontanée par blessure, qui ne fonctionne que pour quelques espèces de végétaux, et la technique très populaire d'exsudation facilitée à l'EDTA, ont également été employées. Toutes ces méthodes ont permis des avancées

\footnotetext{
* Corresponding author.

E-mail addresses: sylvie.dinantiversailles.inra.fr (S. Dinant), jl.bonnemain@oila.fr (J.-L. Bonnemain), girousse@clermont.inra.fr (C. Cirousse), julia.kehr@upm.es (J. Kehr).
} 
importantes pour l'analyse de la composition de la sève et la physiologie des tubes criblés. Un tableau assez complet des métabolites, des ions, des hormones, des protéines et des ARN présents dans la sève du phloème est désormais disponible. Ces avancées ont largement étayé le rôle du phloème comme réseau de signalisation, en plus de son rôle central dans la répartition des photo-assimilats. Ces méthodes d'échantillonnage de la sève élaborée ont aussi des applications potentielles remarquables pour l'analyse de la nutrition, la physiologie et les réactions de défense des plantes. Plusieurs études ayant suggéré que la qualité de la sève phloèmienne pouvait affecter le comportement alimentaire des pucerons, des tentatives de manipulation de la composition de la sève phloèmienne ont été engagées, basées sur la dérégulation des gènes contrôlant la teneur en acides aminés ou en sucres de la sève, dans les plantes transgéniques. De telles approches ouvrent des stratégies nouvelles pour limiter le développement des pucerons sur leur plante hôte et ainsi leur nuisibilité.

(c) 2010 Académie des sciences. Publié par Elsevier Masson SAS. Tous droits réservés.

\section{Introduction}

The phloem is a central actor in plant nutrition and development, allocating nutrients, water, energy and signals from source to sink organs. The conducting tubes, the sieve elements (SE), transport sugars, amino-acids, as well as a range of macromolecules, such as proteins or RNAs, acting potentially in long distance signalling in response to developmental or stress triggers [1-3]. SE are enucleated cells that mostly rely for the delivery of metabolites and macromolecules present in SE on the biosynthesis machinery of the adjacent companion cells (CC) or transfer cells. SE have developed sealing mechanisms, using both callose deposition and P-proteins. While callose deposition can remain for some time, in legumes, changes in P-protein conformation can reversibly and transiently interrupt mass flow and prevent sap leakage following injury [4]. The collection, storage and delivery of metabolites, such as sugars, is achieved through symplasmic and apoplasmic steps taking place in the whole phloem tissue, including $\mathrm{CC}$ and phloem parenchyma cells. Additionally, specialised storage cells, such as M-cells (that store myrosinases in crucifers [5]), or in some species laticifers or secretory ducts, often associated with vascular bundles [6], can also participate in the delivery of the secondary metabolites found in phloem sap. The sap is transported from source (i.e. photosynthetically active) to sink organs by mass flow, which is driven by a difference in hydrostatic pressure between source and sink [7]. Depending on plant species, there are three recognized strategies of sugar loading: apoplastic and symplastic with or without polymer trapping [8]. Apoplasmic loading is associated to the activity of membrane transporters whereas symplasmic loading relies on transport across plasmodesinata.

A basic characteristic of long distance translocation via the phloem is that not all sinks are supplied by the same source leaves. Source leaves can be connected in an independent succession known as orthostichy. The architecture of otthostichy is based on the phyllotaxy of the plant. For example, Arabidopsis has a 3/5-spiral leaf phyllotaxy, which means that every fifth leaf is vertically aligned after three spirals around the plant and leaves in an otthostichy are arranged approximately on a vertical line [9]. The pathway of systemic signalling in response to various stresses, such as wounding, herbivory, or pathogen attack, follows this pattern along orthostichies [1], as evidenced by the demonstration that the translocation of systemic signal molecules, such as salicylic acid, essentially moves with assimilate movement along an orthostichy [10|. Another well-established example of this phenomenon is the pattern of systemic colonization during viral infection, which also follows phloem connections and therefore orthostichy [11]. These observations have confirmed a major role of phloem in long distance signalling, although other signalling pathways acting over long distances have been discovered, especially in plant defense responses [1,12], which recruit airborne signals, such as volatile organic compounds (VOC), and signals transported between phloem and xylem $[10,13 \mid$.

\section{Stylectomy and comparison with other sampling methods}

Over the last decades, the composition of the phloem sap has been studied in detail. Three main methods are available for sampling this fluid. Simple incisions into the phloem of cettain trees (e.g. Fraximus americana, Robinia pseudaacacia) and certain herbaceous plants (e.g. Yucca filamentasa, Cucurbita maxima and other members of the Cucurbita genus, Ricinus communis or Brassica napus) provide relatively large volumes of phloem sap that can be collected for analysis [14,15]. For example, Yucca and palms can provide several liters of phloem sap [3] and Cucurbita maxima can provide milliliters of sap. However, the method based on spontaneous exudation does not work in most plant species, because of a rapid arrest of bleeding, probably due to callose deposits and P-protein accumulation in the sieve plate pores that block the flow. In such a case, EDTA-facilitated exudation, which was initially described by King and Zeevaart, can be employed [16]. This method is based on the use of the calciumchelator ethylene diamine tetraacetic acid (EDTA) in the collecting solution where the distal tips of cut petioles or stems are plunged. The addition of EDTA to the collecting solution is thought to prevent callose synthesis and Pprotein plugging, processes that are normally induced by $\mathrm{Ca}^{2+}$ decompartimentalization in response to phloem injuries. The method of EDTA-facilitated exudation is quick and easy but does not allow the measurement of 
component concentrations. It may induce several artefacts in the composition of the phloem sap, as mentioned below, although it appeared as useful for some applications [17].

Stylectomy is anguably the most elegant method, originally outlined by Kennedy and Mittler [18|. It requires the help of aphids or other phloem feeding insects, such as the brown plant hopper Nilaparvata lugens. It is based on cutting insect stylets that are inserted in a sieve tube while the herbivore is feeding. In the pioneer experiments, the stylets were severed by a razor-blade or microscissors. However, this technique is only feasible for big aphids settled on woody species such as the willow aphid [19]. Subsequently, laser microcautery and radiofrequency microcautery have been used to cut aphid stylets of various sizes, since the first experiments initiated by Barlow and McCully in 1972 and Downing and Unwin in $1977[20,21]$.

The stylectomy method, which is less invasive than EDTA-facilitated exudation, allows collection of relatively pure phloem sap but this does not guarantee that the phloem sap content, especially the amino acid content, is not somewhat manipulated by aphid signals, which are produced in a process called facilitation, or by the initial wounding injury [22]. These potential secondary effects can be minimised or abolished by cutting stylets shortly after the aphids statted feeding. The comparative analyses of phloem sap collected either by stylectomy or EDTAfacilitated exudation from the same plant species highlighted the artefacts induced by the latter method: changes in sugar and amino acids composition [23] and presence of large amounts of contaminative proteins [17]. However, changes in amino acid content may be low if the duration of EDTA-facilitated exudation does not exceed a few hours [24|. Reducing the duration of sap collection using EDTA also minimises the effect of ageing on amino acid metabolism and membrane activities. Moreover, spontaneous and abundant phloem sap exudation found in Cucurbito spp. and other species makes the problem of contamination from various cell types caused by cutting less critical. Stylectomy can be a time-consuming and exasperating technique. Stylet exudation is often unpredictable, both in terms of success rate and duration of sap collection, especially when aphids are settled on leguminous species $[19,23,25]$. The duration of stylet exudation from herbaceous species sieve tubes varies from a few minutes to a few hours and the volume of phloem sap from a few nanoliters to about $100 \mathrm{nl}$ (with an exudation rate of $0.5-2 \mathrm{nl}$ per minute).

Foltunately, recent advances in solute and macromolecule analyses have boosted the prospects of this technique. For instance, amino acid analysis by micellar electrokinetic chromatography with laser-induced fluorescence detection allowed the determination of the profile of amino acids in nanolitre volume samples (except methionine for technical reasons) [26]. Nano-flow liquid chromatography linked to a mass spectrometry enabled the detection of sap polypeptides that were undetectable by gel staining [27|. These methods allow the analysis of phloem sap exudates obtained by stylectomy for plant species yielding limited volumes (nanolitre range) of phloem sap. Finally, sophistication of the microcautery technique itself and "employment" of aphid "battalions" led to the collection of phloem sap at an "industrial" scale ( $10 \mu /$ within a few hours) and this contributed to improve transcript and protein analyses [28], a] though the increase in aphid workforce might cause potential problems with both facilitation and saliva injection.

\section{Physicochemical properties of phloem sap}

Analyses of phloem sap obtained either by incisions into the phloem of bleeding plants such as Curcubita spp. or $R$. communis or collected from severed aphid stylets (Table 1 ) indicate that sugars, potassium and amino acids are the main osmotic components $[29,30]$. The values of osmotic pressure of sieve tube sap vary from about $0.8 \mathrm{MPa}$ in Opuntia ficus-indica or Arabidopsis [31-33] to about 2.0 or $2.5 \mathrm{MPa}$ in species such as R. cammunis, Hardeum vulgare, Zea mays and Sonchus oleroceus [34-37]. For comparison, turgor pressure values measured in individua] sieve tubes using severed aphid stylets [20] range from about $0.8 \mathrm{MPa}$ in Salix babylonica [38] to around $1.2 \mathrm{MPa}$ in 5 . oleraceus $[37,39 \mid$. Provided that comparative measurements of osmotic presssure and hydrostatic pressure in both shoot and root are available $[40,41]$, they support the Münch pressure flow theory establishing that the basic mechanism for phloem transpott is thought to be bulk solution flow driven by an osmotically generated pressure gradient $[42,43]$.

Another characteristic of sieve-tube sap is its $\mathrm{pH}$ value that is moderately alkaline, usually between 7.3 and 8.5 , whatever method used to collect the sap, stylectomy or incisions into the phloem [20,44-46]. Acidic pH values sometimes reported in the past using the incision methods were probably due to phloem sap contamination with exudates from xylem vessels, damaged parenchyma cells, or laticifers [45]. The $\mathrm{pH}$ gradient between the symplast of the sieve cell-CC complex and the phloem apoplast $(\Delta \mathrm{pH}$ around 2.5 units) was, three decades ago, the energetic basis of a new hypothesis to explain phloem loading in apoplastic loaders, a $\mathrm{H}^{+}$-sucrose symport energised by a proton pump ATPase [47|. This hypothesis was further supported by additional data. Particularly, measurements of the sieve tube transmembrane potential difference by inserting a microelectrode into sap exuding from severed stylets of the willow aphid gave values of around $-155 \mathrm{mV}$. Addition of sucrose to the medium in which the Salix stem

Table 1

Chemical composition of wheat phloem sap collected using stylectomy (from reference $|29|$ ).

\begin{tabular}{lc}
\hline Compounds & Concentration $(\mathrm{mM})$ \\
\hline 5ucrose & 251.0 \\
Total amino acid & 261.7 \\
$\mathrm{~K}^{+}$ & 299.0 \\
$\mathrm{Cl}^{-}$ & 25.1 \\
$\mathrm{Na}^{+}$ & 5.2 \\
$\mathrm{Mg}^{2+}$ & 4.9 \\
$\mathrm{Ca}^{2+}$ & 0.2 \\
$\mathrm{NH}^{4+}$ & 2.5 \\
$\mathrm{PO}_{4}{ }^{3-}$ & 8.2 \\
$\mathrm{NO}_{3}{ }^{2-}$ & 8.1 \\
$\mathrm{SO}_{4}{ }^{2-}$ & 1.0 \\
\hline
\end{tabular}


was immersed induced a rapid depolarization of the membrane potential [48|. These data are consistent with the concomitant influx of protons and sucrose molecules in the phloem described by other authors [49,50]. In apoplastic loaders such as Vicia faba and Arabidopsis, the plasma membrane $\mathrm{H}^{+}$ATPase generating the two components of the proton motive force $(\Delta \mathrm{pH}$ and potential difference) is highly expressed in $\mathrm{CC}[51,52]$.

\section{Nutrients, micronutrients and other small molecules in phloem sap}

\subsection{Sugars and amino acids}

The main metabolites found in phloem sap are organic compounds, mostly sugars and amino acids (Table 1 ). Three main types of sugars are known to be translocated in the phloem: sucrose, raffinose-family oligosaccharides (RFO: rafinose, stachyose, verbascose, ajugose), and polyols (mannitol, sorbitol). RFO are typically found in polymer trap loaders, whereas polyols are found either in symplasmic or apoplasmic loaders [8]. In many species, sucrose is the most abundant sugar, with concentrations ranging from $340 \mathrm{mM}$ in the sap of Arabidopsis [53] to $1.8 \mathrm{M}$ in the sap of potato [54]. [n cucurbits, RFOs are most abundant, and the additive concentration of sugars in the SE-CCs of minor veins is about $600 \mathrm{mM}$, with stachyose and raffinose concentrations of 330 and $70 \mathrm{mM}$, respectively [55]. In peach and celery, sorbitol or mannitol, respectively, are the main sugars present in phloem sap [56]. Other sugars, such as galactinol and maltose, can also be found at lower concentration. For example, in Arabidopsis, galactinol, raffinose and maltose are detected [57,58]. Reducing sugars, such as glucose and fructose, are usually present as traces in phloem sap and a high ratio of sucrose to hexoses is generally considered consistent with limited contamination of phloem sap exudates with the content of other cell types. Nevertheless, this paradigm is challenged by the recent discovery. using the EDTA facilitated-exudation technique, that members of two plant families, Ranunculaceae and Papaveraceae, translocate more than $80 \%$ of carbohydrates in the form of hexoses [59].

The major transport form of reduced nitrogen in the phloem is amino acids [60|. Ammonium ( $\mathrm{NH}^{+}$) is usually undetectable [61] and nitrate $\left(\mathrm{NO}^{3-}\right)$ is found either at low concentration or undetectable [29,61-63]. The uptake of sucrose and amino acids, and subsequently their concentration in phloem sap, is interdependent [64|. Amino acids can be abundant (Table 2), with concentrations ranging from $0.18 \mathrm{M}$ in Arabidopsis [32], around $0.4 \mathrm{M}$ in alfalfa, wheat, potato and $B$. napus $[25,54,65-67]$ and over $1.23 \mathrm{M}$ in maize [68]. The relative concentrations of amino acids, especially of the four essential amino acids threonine (Thr), histidine (His), tıyptophane (Trp), and valine (Val) vary between plant species [69] (Tab]e 2). One of the amino acids glutamine (Gln), asparagine (Asn), glutamate (Glu) or aspartate (Asp) is often predominant, depending on the plant species, although most essential and non-essential amino acids can be detected $[25,32,70]$. Cysteine (Cys) is present just as a trace in phloem sap, and glutathione was
Table 2

Amino acid content (mM) of phloem sap collected from wheat (Titicum aestivum L.) leaf [29] and alfalfa (Medicago sativa L.) stem [23] using scylectomy.

\begin{tabular}{|c|c|c|}
\hline Amino acid & Wheat (mM) & Alfalfa $(m M)$ \\
\hline Ala & 6.9 & 8.2 \\
\hline Al'g & 6.1 & 5.4 \\
\hline Asn & 10.2 & 273.0 \\
\hline Asp & 51.4 & 18.3 \\
\hline Cys & na & 1.3 \\
\hline Glu & 79.3 & 7.5 \\
\hline Gln & 9.7 & 8.9 \\
\hline Gly & 1.7 & 2.6 \\
\hline $\mathrm{His}$ & 4.9 & 2.6 \\
\hline $\mathrm{Ile}^{\mathrm{a}}$ & 10.6 & 6.1 \\
\hline Leu $^{a}$ & 12.4 & 5.8 \\
\hline Lys $^{\mathrm{a}}$ & 12.4 & 3.3 \\
\hline Met $^{a}$ & 1.8 & n.d. \\
\hline Phe & 8.4 & 4.5 \\
\hline Pro & na & 6.6 \\
\hline $5 e r$ & 14.9 & 15.8 \\
\hline Thr $r^{A}$ & 12.9 & 10.3 \\
\hline $\operatorname{Tr}^{a}$ & na & па \\
\hline Tyг & 5.9 & 1.7 \\
\hline $\mathrm{Val}^{\mathrm{a}}$ & 12.2 & 9.0 \\
\hline$\gamma$-amino butyric acid & n.d. & 1.7 \\
\hline Total essential amino acids & 70.7 & 39.0 \\
\hline Total amino acids & 261.7 & 392.6 \\
\hline
\end{tabular}

Values are obtained from 1 sap sample in the case of wheat and are means of 9 samples in the case of alfalfa.

n.d. non detected; na: not available. Note that in the alfalfa phloem sap. the total of essential amino acids represents only $10 \%$ of the total amino acid content.

a Essential amino acids.

proposed to be the main form of transport of sulfur amino acids [71|, which are found in the sap [72]. In addition to gluthatione, in wheat leaves, the non-protein amino acid Smethylmethionine is also a major form of reduced sulfur in phloem sap [73]. The non-protein amino acid g-aminobutyric acid ( $G A B A)$ is detectable in the sap of some species although a high level of GABA was suggested to be in some cases an altefact of the exudation technique [23|. Other organic components, such as polyamines, are also found in phloem sap [74], and organic acids, especially malic, succinic and citric acid, are normally present in a range of species $[34,61,62]$.

\subsection{Inarganic ians and micronutrients}

Inorganic jons, especially potassium, are present in the phloem sap (Table 1), with concentrations varying between plant species and environmental conditions [29,75]. In Arabidopsis, potassjum, sulphur and phosphorus are found at concentrations of 125,15 , and $25 \mathrm{mM}$, respectively [53]. Potassium, the major cation, plays an impoitant role in provision of turgor and membrane potential, favouring sugar loading in source leaves [53,76] and is also implicated in the transmission of electric signals via membrane depolarisation [77]. Phosphate and other anions, such as bicarbonate and malate, are involved in the charge balance and are thought to play a role in the control of phloem sap pH. Minerals, such as phosphoius can also fluctuate with both daytime and seasons [75,78]. Smal] 
amounts of $\mathrm{Mg}^{2+}$, sodium and chloride are found in the sap. In maize, they accumulate around $1.5,0.7$ and $8 \mathrm{mM}$, respectively, and sodium and chloride increase in response to salt treatment, indicating that phloem translocation of these ions contribute significantly to the leaf solute balance and prevents ion accumulation in apoplasm and symplasm [61]. Micronutrients such as iron, copper, manganese, zinc, boron and molybdenum, are also present [79], although their presence in phloem sap can be divergent in different plant species depending on the mechanisms involved in their translocation. For example, the reallocation of boron via the phloem is only found in species, such as celery, that transport sugar alcohols, which form a complex with boron in the sap [80]. Vitamins, such as thiamine and ascorbic acid (AsA), are also found in phloem sap $[45,72,81]$. In the potato, strong evidence suggests that AsA. which has a major role as antioxidant, is synthesised in source leaves and then translocated via the phloem to sinks organs, such as tubers, although the relative contribution of phloem-derived AsA to overall AsA accumulation in potato tubers is still unknown [82].

Free $\mathrm{Ca}^{2+}$ is also present in phloem sap and appears as important for phloem physiology and signalling. Thus, it was shown to be important for sieve plate occlusion and forisome dispersion in $V$. faba in response to injury $[83,84]$. The estimation of the concentration of $\mathrm{Ca}^{2+}$ in the phloem sap was a matter of debate for a long time. It was determined using both $\mathrm{Ca}^{2+}$-selective electrodes and fluorescent $\mathrm{Ca}^{2+}$-sensitive dyes. In $V$. faba, it has been estimated to be around $50 \mathrm{nM}$, rising in response to wounding up to $200 \mathrm{nM}$, establishing that free $\mathrm{Ca}^{2+}$ is present in a concentration range similar to that found in other cell types [85], although much lower than previously estimated for phloem sap of $R$. cammunis [86].

\subsection{Secandary metabalites, hormones and lipids}

A large range of secondary metabolites accumulate in phloem sap, but the content varies a lot and depends on the plant species. Phenolic glycosides, for example, are found in Salicaceae [87], glucosinolates in Brassicaceae [88], cardenolides [89] and jridoid glycosides [90-92] in Scrophulariaceae or Bignonjaceae, quinolizidine and pyrrolizidine alkaloids in Fabaceae [93-95] and glycosides of hydroxamic acid in Poaceae [96|. Only one comprehensive survey of the metabolome of the phloem sap was achieved in pumpkin by analysis of bleeding sap [97]. This study established a lange range of compounds besides sucrose and amino acids, such as organic acids, a range of sugars, hexose phosphates, polyamines, aromatic amino compounds and small hydroxy acids [97].

In addition, many phytohormones have been identified in phloem sap [98], including auxin, cytokinins, gibberellins, abscisic acid, 1-aminocyclopropane-1-carboxylic acid (the precursor of ethylene), methyl jasmonate, and salicylic acid [13,99-112]. In contrast, brassinosteroids were not reported. Other signal molecules, such as nitric oxide, are detected in phloem sap of $V$. faba [113]. The dicarboxylic acid, azelaic acid, is found in Arabidopsis phloem sap and acts in systemic resistance in the priming of systemic immunity [114]. Only a few reports analysed the amounts of lipids and sterols present in the sap. In canola, the phloem lipid composition is clearly distinguishable from that of membranes and previously characterised lipid particles [107]: it includes phospholjpids, diacylglycerol, triacylglycerol, steryl wax esters and unesterified fatty acids. Some of these fatty acids might patticipate in signalling pathways. Some sterols, such as sitosterol, are phloem mobile as reported in barley sap samples [115].

\section{Effects of environmental factors and stresses on the nutrient content of phloem sap}

As previously stated, sugars, amino acids and $\mathrm{K}^{+}$are the dominant solutes and account for the majority of the osmotic potential [116| and their overall concentration maintains a relatively stable rate of transport into the SE independent of day-night transitions or climatic variations $[75,117]$. However, the precise composition of phloem sap is influenced by multiple timescales: from the diurnal cycle to the season $[65,75,118-123 \mid$; by the developmental age of the plant $[72,97,123-125]$.

It is also influenced by abjotic factors, such as temperature, nitrogen and water availability $[67,70,126]$.

lt was shown that the $\mathrm{C} / \mathrm{N}$ ratio fluctuates along the diurnal cycle and plant development $[118,124 \mid$, consistent with the interdependance of sugar and amino acid uptake [64]. Thus, the levels of total amino acids, sucrose and $\mathrm{K}^{+}$ jons in phloem exudates present an overall diurnal periodicity $[119,120,127]$. Analyses of wheat phloem sap collected from aphid stylets also indicate complex diurnal variations of individual amino acids. The increase of amino acid content during the afternoon is correlated to a covariation of Arg, Tyr, Phe, His/Val, Leu/lle, Pro and Asn concentrations, while the level of the other amino acids remains unchanged [65].

Furthermore, specific changes in amino acid composition can be induced by abiotic stresses. For instance, the technique of EDTA-facilitated exudation induces a variety of artefacts, notably a drop of Asn content and a strong increase of GABA [23]. These data are consistent with previous observations indicating that GABA dramatically accumulates in leaf tissues floating on an incubation medium [128]. On the other hand, a decrease of the predawn water potential of alfalfa leaves from -1 to $2 \mathrm{MPa}$ induced an increase of the total amino acid concentration mostly due to certain amino acids, especially Pro (60-fold increase), Val, Leu, lle, Glu, Asp and Thr [25]. These and other data, such as the observation of a synthesis of Pro and an induction of amino acid transporter in leaves in response to a water deficit $[129,130]$ contribute to explain the dramatic accumulation of Pro observed in the growing region of the primary root in response to drought [131|. Specific changes in amino acid composition of phloem sap can also be noted in cases of biotic stress. For example, the infestation of wheat plants by aphids such as Schizaphis graminum and Diuraphis noxja, which induce chlorotic lesions, led to modification of phloem sap composition, especially to an increase of amino acid concentration, particularly Gln and the essential amino acids His, lle, Leu, Met, Phe, Trp and Val [132]. These 
changes can be in some cases nutritionally advantageous for the aphids and can even be induced by an aphidmediated facilitation process during feeding, as mentioned earlier on.

Finally, phloem sap composition is far from being uniform across SE, as illustrated by the variation in amino acid concentration among replicate samples of exudates from severed stylets $[25,65,133]$.

\section{Alteration of phloem sap composition and downstream effects on plant aphid interactions}

Variation in the performance and abundance of aphids has been suggested to be correlated to variation in host plant quality $[70,79,134-136$ and more specifically to the sugar, amino acid and sucrose: amino acid ratio in phloem sap. In order to test for this hypothesis, aphid growth and fecundity were first evaluated using sap-copied holidic diets differing by their amino acid or sucrose concentrations [137]. More recently, several groups investigated aphid performance on transgenic plants, in which phloem sap sugar or nitrogen content was modified.

\subsection{Modjificatian of sugar content and aphid setrlement and feeding}

Sugars accumulate to high concentrations within phloem sap and are responsible for a high osmotic pressure in the aphid diet, which in turn requires a strong osmoregulation within the insect body [136]. Modification of sugar content in phloem sap has been achieved by different approaches, modifying either carbon metabolism in mesophyll cells or sucrose transport in the phloem. For example, the alteration of the accumulation of triose phosphate translocator or ADP-glucose pyrophosphorylase in potato in antisense transgenic lines [122] led to a modification of day/night sugar composition in the sap. Other approaches were based on the alteration of sugar transpotters, which are required for apoplasmic loading. To date, only one report studied the aphid responses to alteration of phloem sap sugar content. The analysis of potato plants affected in sugar transporter StSut 1 , which were affected in the amount of sucrose present in phloem sap, showed no effect on the performance of Myzus persicae and Aulacorthum solani. Only Macrasiphon euphorbiae performed worse on these lines, suggesting that these aphids are dependent on a high sugar concentration in phloem sap to successfully colonise potato leaves [54]. Since sucrose has been suggested to act as a phagostimulant [79,138,139], the authors concluded that aphid feeding might be promoted by temporal variations in sucrose composition [54]. In this study, aphid behaviour was recorded using electric penetration graph (EPG), a technique based on electric recording of aphid behaviour during the successive steps of feeding [140].

\subsection{Modificatian of amino acid content and aphid perfannance}

It is well accepted that the supply of nitrogen in the form of free amino acids is a limiting factor in the aphid diet for growth and fecundity [79]. Moreover, nine amino acids cannot be synthesised by the aphids and have to be present in the diet [136]. Uptake and transport of amino acids is controlled by a number of amino acid transporters expressed in various tissues, including phloem, and displaying a large range of affinity and substrate specificity [141], in close relationship with nitrogen remobilisation mechanisms. Attempts to manipulate amino acid sap composition were based on the deregulation of genes encoding amino acid permeases in Arabidopsis [32,33]. ANT1 is a permease that displays moderate affinity for neutral and aromatic amino acids [142|. In the knockout mutant ANT1, the contribution of several amino acids was increased in phloem sap, consistent with the hypothesis that ANT1 moves amino acids out of the SE [33]. However, no significant differences in the feeding behaviour and fecundity for $M$. persicae aphids feeding on the mutant could be detected [33]. AAP6 is a neutral amino acid permease with high affinity [129]. It is mainly expressed in sink tissues and is thought to mediate the transfer of amino acids from the xylem to the phloem. Although knockout mutants presented a clear decrease in amino acids in the phloem sap. $M$. persicae feeding on the mutant showed only limited alteration of their metabolism, behaviour and reproduction, besides a mild effect on salivation time [32], as monitored by EPG.

It is becoming clear that prediction of aphid performance is more complex than a simple correlation with the nitrogen content of the diet, many other metabolite factors potentially contributing to output [32|. Moreover, the endosymbiotic bacteria Buchnera enables aphids to subsist on a unbalanced amino acid diet provided by phloem sap $[136,143]$ by synthesising severa] essential lacking amino acids from relatively abundant non essential phloem amino acids [143,144] or possibly from other sources, such as the non-protein amino acid S-methylmethionine, which was suggested to be a potential precursor [145].

\section{Phloem sap macromolecules in relation to defence against phloem feeding insects}

\subsection{Pratein cantent and trafficking}

An exciting field of recent investigations is the identification of a large range of proteins in phloem sap [17,146-150]. Protein content in phloem sap ranges from 0.1 to $1 \mathrm{mg} / \mathrm{ml}$ in most plants up to $30 \mathrm{mg} / \mathrm{ml}$ in cucurbit exudates [148], and protein sizes range from 1 to more than $100 \mathrm{kDa}$. Since the size exclusion limit of plasınodesmata between $\mathrm{CC}$ and $\mathrm{SE}$ is up to $67 \mathrm{kDa}[151 \mid$, it is be]ieved that sorting mechanisms enable larger proteins to be unfolded to enter the sieve tubes via plasmodesmata [2]. In addition, some of these proteins traffic long distance within sieve tubes and act in long distance signalling [2,3|. For example, the protein FT was shown to act as the phloem long distance signal for flower induction in Arabidopsis [152], and the long distance transport of the transcript of BEL1 through the phloem is correlated with tuber formation in potato [153].

Phloem sap proteomes were analysed in rice, melon, cucumber, pumpkin, $B$. napus and $R$. communis 
[17,27,146,148-150,154-157]. One striking feature is the abundance of enzymes involved in redox regulation and antioxidant defence systems $[155,158]$. They include the enzymes peroxidase, ferredoxin, monodehydroascorbate reductase, dehydroascorbate reductase, Cu/Zn superoxide dismutase, and thioredoxin $\mathrm{H}[150,155,159,160 \mid$. Also, other defence proteins were reported in several phloem sap analyses [157]. Since sieve tubes are the targets of aphids, such proteins were proposed to be involved in protection mechanisıns against phloem feeding insects [158]. The set of putative defence proteins includes protease inhibitors, lectins, components of the myrosinase system (found in crucifers), some proteins known to be induced by wounding or insect feeding (CSF-2, SN-1, SLW1, SLW-3), and enzymes involved in the biosynthesis of jastnonic acid or ethylene [158|. Many components of signal transduction pathways were found, including kinases, calcium binding proteins, annexins or calmodulin [158], which can act either in the activation of $\mathrm{Ca}^{2+}$-binding kinases or in $\mathrm{Ca}^{2+}$ sequestration to prevent occlusion of sieve tubes $[84,85 \mid$. P-proteins, especially phloem lectins, that are thought to act on the transient and reversible occlusion of SE following phloem injury, were also frequently found [158].

Some phloem sap proteins are also involved in RNA trafficking in the phloem [2] and RNA-binding proteins were consistently found in phloem sap. In pumpkin sap, at least 82 proteins annotated as RNA-binding were described [157]; they include CinPP16, ComPP1, CmPP2, glycine-rich RNA binding proteins and elF-5A, a putative component of the protein synthesis machinery, and helicases. Some of these proteins were proposed to be involved in the unfolding and refolding of RNAs trafficking through plasmodesmata between $C C$ and SE $[2,157 \mid$.

Enzymes involved in the metabolism of sugars appear enriched in pumpkin sap exudates, consistent with the possibility of a conversion of sugars into hexoses [157]. Components of the cytoskeleton, actin, actin associated proteins and profilin, were reported in several surveys $[150,157]$. Of particular interest is the discovery of many components of the ubiquitin proteasome complex found in pumpkin sap, rice and rape. Such components are thought to participate either in protein turnover or in defence or developmental signalling pathways $[161,162 \mid$. To date, there is no report of proteome analysis of phloem sap in response to aphid feeding, although there are potentially many proteins in phloem sap that could be acting in response to aphids.

Eventually, when delivered into sieve tubes, proteins which are not anchored to membranes are translocated long distances by bulk flow, as demonstrated for the green fluorescent protein (GFP) that moved non-selectively in sieve tubes [163]. Nevertheless, whereas translocation towards the shoot appears to be passively cartied by bulk flow, movement of some phloem RNA-binding proteins in the direction of the root was selectively regulated [164], suggesting that the delivery of macromolecules into sink tissues might be tightly controlled. However, our understanding of the control mechanisms for long-distance movement remains limited, particularly due to the difficulty to observe long distance trafficking of macromolecules in vivo. Evidence of a destination-selective translocation of phloem proteins was obtained in rice, using the MUSI (micro-introduction using stylet of insect) method [165] and the brown planthopper $N$. lugens. The approach is based on application of fluorescent or biotinylated tagged tracer protein to the cut stylet of the insect, which allowed for protein diffusion into the sieve tube, then incorporation into the phloem translocation stream and observation of its long distance delivery into distant organs $[164,165]$. Using tagged CmPP16 proteins from C. maxima, the authors demonstrated that both CinPP16-1 and CmPP16-2 form a complex with rice phloem sap proteins, whereas CmPP16-1 is translocated towards the root in addition to the shoot, in contrast to CinPP16-2 that moves only towards the shoot. These results suggest that the selective movement is regulated by protein-protein interactions and the formation of complexes in phloem sap [164].

In addition to CmPP16 proteins, various proteins have been identified in such complexes, including, for example, a translationally controlled tumor-associated protein (TCTP), an eukaryotic translation initiation factor 5A (eIF5A), a polypyrimidine tract binding protein, (RBP50) and a molecular chaperone $\mathrm{Hsc} 70$ found in rice or pumpkin phloem sap $[164,166]$. Some of these proteins are RNAbinding proteins and are though to form ribonucleoprotein complexes acting on the translocation of the RNA present in phloem sap.

\section{RNAs species and trafficking}

Various RNA molecules have thus been found in SE sap, and these phloem-mobile RNAs are thought to act in long distance signalling $[2,167,168 \mid$. They include InRNAs, SIRNAs, miRNAs, IRNAs and tRNAs. Hundreds of mRNAs have been identified in the phloem sap [28,167,169-171|. These mRNAs encode proteins involved in a range of functions, including transcription factors, stress response proteins, metabolic enzymes, transporters or other stiuctural components. The subset of mRNAs present in the phloem sap appears distinct from those present in other tissues or organs [172]. For example, in melon a higher percentage of transcripts related to stress and stimulus responses, metal-ion binding, proteinase-inhibitor activity, and the ubiquitin-ligase complex was found in phloem sap compared to leaves and fruits [170]. In Arabidopsis, the transcript profile of phloem sap does not reflect the profile of $\mathrm{CC}$, indicating that not all transcripts of the $\mathrm{CC}$ are transported into the SE [172|. ]mportantly, not all mRNAs are transpoited long distances, as demonstrated in the melon, in which only a small fraction of mRNAs were translocatable through graft junctions [170]. This suggests that besides long distance signalling, other functions may be undertaken by these RNAs.

Small RNAs, including siRNAs and miRNAs, were jdentified in C. maxima, Cucumis mela, Lupinus albus and B. napus [173-175]. The siRNAs are non-cell autonomous and are indeed very abundant in phloem sap where they act on systemic silencing [176|. The presence of severa] miRNAs, usually considered as cell autonomous [177] is perhaps more surprising. Additionally, specific miRNAs 
found in phloem sap are regulated by abiotic stresses, as demonstrated for sulphate, phosphate or copper deficiency $[174,175,178]$. This suggests that stress-induced miRNAs could possibly act as systemic silencing signals between distant organs. Other classes of small RNAs, i.e. rRNAs and tRNAs, have also been detected in phloem sap exudates. The observation of tiuncated tRNAs, presenting inhibitory activity in in vitro translation assays is consistent with involvement in a regulatory mechanism to down-regulate protein synthesis [179].

Interestingly, some RNAs present in phloem sap can also be delivered to plant parasites. For example, in the host-parasite junction of Cuscuta pentagana with tomato, several mRNAs were found to move from host to the dodder [180,181]. Some of the genes with mobile transcripts have roles in mediating plant response to the environment [180], and were proposed to allow some coordination between the parasite and its host [181]. This observation provides the potential to use gene-silencing technologies to increase resistance of crop plants against parasites by exploiting the interspecific trafficking of small interfering RNAs to target vital functions in the parasite. The use of dsRNA or RNA interference expressed in planta has already been validated against the western corn rootworm and the cotton bollworm $[182,183 \mid$.

\section{Conclusion and perspectives}

Aphid stylectomy, spontaneous exudation and EDTAfacilitated exudation have been successfully used in many studies that have significantly increased our knowledge of phloem sap composition. Despite its technical difficulty. the use of aphid stylectomy is an useful tool for collecting SE sap so that its composition can be analysed, for studying phloem function and integrating with other aspects of plant biology. It minimises many sampling artefacts caused by wounding, not withstanding that aphids do manipulate their host and induce in the phloem tissue gene expression reprogramming [184|. Stylectomy was used for investigations on phloem sap main metabolites, such as sugars, amino acids or $\mathrm{K}^{+}$, that contributed to a better understanding of phloem physiology. Other potential applications are possible. Recently, it was used for analysing the unexpected secondary positive effects of transgenic maize lines expressing the Bocillus thuringiensis toxin on the performance of a non targeted insect feeding on these plants, the aphid Rhopalasiphum maidis. In these plants, the amino acid content in phloem sap was proposed to partially explain the observed increased aphid performance [68]. Nevertheless, application of stylectomy is mainly restricted to plant species on which phloem feeding insects can produce extended and abundant exudation, such as rice or maize $[27,44,68]$, although several other plants, such as potato or Arabidopsis, were recently successfully used for analysis of abundant SE components, despite exudation volumes in the nanoliter range $[32,33,54]$.

Many studies on phloem sap composition have been performed on the polymer trap loader cucurbits that allow the collection of large amounts of phloem exudates from simple incisions $[147,149,155,157,170,173]$. Other species, such as B. nopus or $R$. communis, that also spontaneously exude upon wounding, also emerged as additional useful models for phloem sap analysis $[150,156,169,174]$.

Besides stylectomy, other techniques based on the use of aphids are currently being developed to extract and analyse phloem sap. Limited so far to rice, the MUS] technique [165] was shown to be an efficient technique for studying macromolecular trafficking through sieve tubes. EPG [140] can be useful for plant physiologists, since it can show alteration in the feeding behaviour of an insect on different plants, which might indicate variations in the content of phloem or other cell layers. For example, it was used to demonstrate the role of PAD4 (phytoalexin deficient 4), a lipase-like protein involved in the regulation of defence, in the control of the phloem phase of feeding of $M$. persicae in Arabidopsis [185]. EPG was also applied to demonstrate that the plugging of sieve plates by forisomes induced by burning affects the behaviour of the aphid Megouro viciae on $V$. faba [186].

These advances in phloem physiology have contributed to identifying new cues potentially controlling plant aphid interactions. So far, this has largely been achieved using mutant plants in which genes encoding for sucrose or amino acid transporters were knocked out $[32,33,54]$. The potential of such approaches in limiting aphid performance in the field still needs to be established and as reported here, it is clear that the interaction between plants and aphids is not as clear as earlier proposed. This indicates that plant-aphid interactions are probably subtly regulated and involve a range of nutrients, repellents and volatiles, and that a better understanding of metabolism, transport and signalling in the phloem will potentially provide new targets for strengthening plant defence against aphids.

\section{References}

[1] A.J. van Bel, F. Gaupels, Pathogen-induced resistance and alarm signals in the phloem, Mol Plant Pathol 5 (2004) 495-504.

[2| T.]. Lough, W.]. Lucas, Integrative plant biology: role of phloem longdistance macromolecular trafficking. Annu Rev Plant Biol 57 (2006) 203-232.

[3| R. Turgeon, 5. Wolf, Phloem transport: cellular pathways and molecular trafficking, Annu Rev Plant Biol 60 (2009) 207-221.

[4] A.].E. van Bel, K. Ehlers, M. Knoblauch, Sieve elements caught in the act, Trends Plant Sci 7 (2002) 126-132.

[5] H. Husebye, S. Chadchawan, P. Winge, O.P. Thangstad, A.M. Bones, Guard cell- and phloem idioblast-specific expression of thioglucoside glucohydrolase 1 (myrosinase) in Arabidopsis, Plant Physiol 128 (2002) 1180 .

[6] W.F. Piclurd, Laticifers and secretory ducts: two other tube systems in plants, New Phytol 177 (2008) 877-888.

[7] A.J, van Bel, The phloem, a miracle of ingenuicy. Plant Cell Environ 26 (2003) 125-149.

[8] E.A Rennie, R. Turgeon, A comprehensive picture of phloem loading strategies, Proc Natl Acad Sci U S A 106 (2009) 14162-14167.

[9] J.D. Callos, J.L. Medford, Organ positions and pattern formation in the shoot apex. Plant I 6 (1994) 1-7.

[10] I.W. Kiefer, A.J. Slusarenko, The pattern of systemic acquired resistance induction within the Arabidopsis rosette in relation to the pattern of translocation. Plant Physiol 132 (2003) 840-847.

[11] K. Roberts, A.J. Love, V. Laval, J. Laird, AD. Tomos, M.A. Hooks, J.J. Milner, Long-distance movement of Cauliflower mosaic virus and host defence responses in Arabidopsis follow a predictable pattern that is determined by the leaf orthostichy. New Phytol 175 (2007) 707717.

[12] M. Heil, J. Ton, Long-distance signalling in plant defence, Trends Plant Sci 13 (2008) 264-272. 
[13] M. Thorpe, A. Ferrieri, M. Herth, R. Ferrieri, 11C-imaging: methy jasmonate moves in both phloem and xylem, promotes transport of jasmonate, and of photoassimilate even after proton transport is decoupled, Planta 226 (2007) 541-551.

[14] W Eschrich, W. Heyser, Biochemistry of phloem constituents, in: M.H. Zimmermann, J.A. Milburn (Eds.), Encyclopedia of Plant Physiology, Transport in Plants I, Phloem Transport, Springer-Verlag. New York. 1975, pp. 101-136.

[15] A.J. Peel. Investigations with aphid stylets into the physiology of the sieve tube, in: M.H. Zimmermann, J.A. Milbum (Eds.), Encyclopedia of Plant Physiology. Transport in Plants I, Phloem Transport, SpringerVerlag, New York, 1975, pp. 171-195.

[16] R.W. King, J.A.D. Zeevaart, Enhancement of phloem exudation from cut petioles by chelating agents, Plant Physiol 53 (1974) 96-103.

[17] F. Gaupels, T. Knauer, AJ.E. van Bel, A combinatory approach for analysis of protein sets in barley sieve-tube samples using EDTAfacilitated exudation and aphid stylectomy.J Plant Physiol 165 (2008) 95-103.

[18] J.S. Kennedy, T.E. Mittler, A method of obtaining phloem sap via the mouth-parts of aphids. Nature 171 (1953) 528.

[19] D.B. Fisher, J.M. Frame, A guide to the use of the exuding-stylet technique in phloem physiology. Planta 161 (1984) 385-393.

[20] CA. Barlow, M.E. McCully. The ruby laser as an instrument for cutting the stylets of feeding aphids, Can J Zool 50 (1972) 1497-1498.

[21] N. Downing, D.M. Unwin, A new method for cutting the mouthparts of feeding aphids, Physiol Entomol 2 (1977) 275-277.

[22] F. Divol, F. Vilaine, S. Thibivilliers, J. Amselem, J.C. Palauqui, C. Kusiak S. Dinant, Systemic response to aphid infestation by Myzus persicae in the phloem of Apium groveolens. Plant Mol Biol 57 (2005) 517-540.

[23] C. Girousse. J.-L. Bonnernain. S. Delrot, R. Bournoville, Sugar and amino acid composition of phloem sap of Medicago sativa: a comparative study of two collecting methods. Plant Physiol Biochem 29 (1991) 4148.

[24] J. Weibull, F. Ronquist, S. Brishammal, Free amino acid composition of leaf exudates and phloem sap: a comparative study in oats and barley. Plant Physiol 92 (1990) 222-226.

[25] C. Girousse, R. Boumoville, J.L. Bonnemain, Water deficit-induced changes in concentrations in proline and some other amino acids in the phloem sap of Alfalfa, Plant Physiol 111 (1996) 109-113.

[26] X. Zhu, P.N. Shaw, J. Phitchard, J. Newbury, E.J. Hunt, D.A. Barrett, Amino acid analysis by micellar electrokinetic chromatography with laser-induced fluorescence detection: Application to nanolitre-volume biological samples from Arabidopsis tholiano and Myzus persicae. Electrophoresis 26 (2005) 911-919.

[27] T. Alki, M. Shigyo, R. Nakano. T. Yoneyama, S. Yanagisawa, Nano scale proteomics revealed the presence of regulatory proteins including three FT-Like proteins in phloem and xylem saps from rice. Plant Cell Physiol 49 (2008) 767-790.

[28] F. Gaupels, A. Buhtz, T. Knauer, S. Deshmukh, F. Waller, AJ. van Bel, K.H. Kogel, J. Kehr, Adaptation of aphid srylectorny for analyses of proteins and mRNAs in barley phloem sap, J Exp Bot 59 (2008) 3297 3306.

[29] H. Hayashi, M. Chino, Collection of pure phloem sap from wheat and its chemical composition, Plant Cell Physiol 27 (1986) 1387-1393.

[30] J.W. Patrick, W.H. Zhang, S.D. Tyerman, C.E. Offler, N.A. Walker, Role of membrane transport in phloem translocation of assimilates and water, Aust J Plant Physiol 28 (2001) 695-707.

[31] N. Wang, PS. Nobel, Phloem exudate collected via scale insect stylets from the CAM species Opuntia ficas-indica under current and doubled $\mathrm{CO}_{2}$ concentrations. Ann Bot 75 (1995) 525-532.

[32] E. Hunt, S. Gattolin, H.J. Newbury, JS. Bale, H.-M. Tseng, DA. Barrett, J. Pritchard, A mutation in amino acid pelmease AAFo reduces the amino acid content of the Arabidopsis sieve elements but leaves aphid herbivores unallected, J Exp Bot (2009) (erp274).

[33] E.J. Hunt, J. Pritchard, M.J. Bennett, X. Zhu, D.A. Barrett, T. Allen, J.S Bale, H.J. Newbury, The Arabidopsis thaliana/Myzus persicae model system demonstrates that a single gene can influence the interaction between a plant and a sap-feeding insect, Mol Ecol 15 (2006) 42034213.

[34] J.A.C. Smith, J.A. Milburn, Osmoregulation and the control of phloemsap composition in Ricinus conmunis L, Planta 148 (1980) $28-34$.

[35] R.D. Warmbrodt, Solute concentrations in the phloem and associated vascular and giound tissues of the root of Hordeum valgare $\mathrm{L}$, in: J. Cronshaw, W.J. Lucas, RT. Giaquinta (Eds.), Phloem transport, Alan R. Liss Inc. New Yolk, 1986, pp. 435-444.

[36] R.D. Warmbrodt, Solute concentrations in the phloem and the apex of the root of Zea mays, Amer J Bot 74 (1987) 394-402.

[37] N. Gould, M.R. Thorpe, O. Koroleva, P.E.H. Minchin. Phloem hydiostatic pressure relates to solute loading rate: a direct test of the Münch hypothesis, Funct Plant Biol 32 (2005) 1019-1026.
[38] J.P. Wright, D.B. Fisher, Direct measurement of sieve tube turgor pressure using severed aphid srylets, Plant Physiol 65 (1980) 11331135.

[39] N. Gould, P.E.H. Minchin, M.R. Thorpe, Direct measurements of sieve element hydrostatic pressure reveal strong regulation after pathway blockage, Funct Plant Biol 31 (2004) 987-993.

|40| J. Pritchard, Aphid srylectomy reveals an osmotic step between sieve tube and cortical cells in barley roots, J Exp Bot 47 (1996) 1519-1524.

[41] N. Gould, M.R. Thorpe. P.E.H. Minchin, J. Pritchard, P.J. White, Solute is imported to elongating root cells of barley as a pressure driven-flow of solution, Funct Plant Biol 31 (2004) 391-397.

[42] P.E.H. Minchin, A. Lacointe, New understanding on phloem physiology and possible consequences for modelling long-distance cabon transport, New Phytol 166 (2005) 771-779.

[43] M.V. Thompson, Phloem: the long and the short of it, Trends Plant Sci 11 (2006) 26-32.

[44] T. Fukumorita, M. Chino, Sugar, amino acid and inorganic contents in rice phloem sap, Plant Cell Physiol 23 (1982) 273-283.

[45] H Ziegler, Nature of transported substances, in: M.H. Zimmelmann. JA. Milbum (Eds.). Encyclopedia of plant physiology, transport in plants I, phloem transport, Springer-Verlag, New York, 1975, pp. 59-100.

[46] H. Marschner, E. Kirkby, I. Cakmak, EПect of mineral nutritional status on shoot-root partitioning of photo-assimilates and cycling of mineral nutrients, J Exp Bot 47 (1996) 1255-1263.

[47] R.T. Giaquinta, Possible role of pH gradient and membrane ATPase in the loading of sucrose into the sieve tubes, Nature 267 (1977) 369370.

[48] J.P. Wright, D.B. Fisher, Measurement of the sieve tube membrane potential, Plant Physiol 67 (1981) 845-848.

[49] S. Delrot, Proton fluxes associated with sugar uptake in Vicia faba leaf tissues, Plant Physiol 68 (1981) 706-711.

[50] S. Delrot, ].L Bonnemain, Involvement of protons as a substrate for the sucrose carrier during phloem loading in Vicia faba leaves. Plant Physiol 67 (1981) 560-564.

[51] S. Bouché-Pillon, P. Fleurat-Lessard, J.C. Fromont, R. Serrano, J.L. Bonnemain, Immunolocalization of the plasma membrane $\mathrm{H}+-$ ATPase in minor veins of Vicia faba in relation to phloem loading, Plant Physiol 105 (1994) $691-697$

[52] N.D. DeWitt, M.R. Sussman, Immunocytological localization of an epitope-tagged plasma membrane proton pump ( $\mathrm{H}+-\mathrm{ATPase})$ in phloem companion cells, Plant Cell 7 (1995) 2053-2067.

[53] R. Deeken, D. Geiger, J. Fromm, O. Koroleva, P. Ache, R. LangenfeldHeyser, N. Sauer, S. May, R. Hedrich, Loss of the AKT2/3 potassium channel affects sugar loading into the phloem of Arabidopsis, Planta 216 (2002) 334-344.

[54] K.V. Pescod, W.P. Quick, A.E. Douglas, Aphid responses to plants with genetically manipulated phloem nutiient levels. Physiol Entomol 32 (2007) 253-258.

[55] E. Haritatos, F. Keller, R. Turgeon, Raffinose oligosaccharide concentrations measured in individual cell and tissue types in Cucamis meio $\mathrm{L}$. leaves: implications for phloem loading. Planta 198 (1996) 614-622.

[56] J. Nadwodnik, G. Lohaus, Subcellular concentrations of sugar alcohols and sugars in relation to phloem translocation in Plantogo major Plantago maritima, Prunus persica, and Apium graveolens, Planta 227 (2008) 1079-1089.

[57] E Haritatos, R. Medville, R. Turgeon, Minor vein structure and sugar transport in Arabidopsis thatiana, Planta 211 (2000) 105-111.

[58] Y. Lu, J.M. Strichen, S.E. Weise, T.D. Sharkey, Cellular and organ level localization of maltase in maltose-excess Arabidopsis mutants, Planta 224 (2006) 935-943.

[59] A.J. van Bel, P.H. Hess, Hexoses as phloem transport sugars: the end of a dogma? J Exp Bot 59 (2008) 261-272.

[60] B. Riens, G. Lohaus, D. Heineke, H.W. Heldt, Amino acid and sucrose content determined in the cytosolic, chloloplastic, and vacuolar compartments and in the phloem sap of spinach leaves, Plant Physiol 97 (1991) 227-233.

[61] G Lohaus, M. Hussmann, K. Pennewiss, H. Schneider, J.-J. Zhu, B. Sattelmacher, Solute balance of a maize (Zea mays L) source leaf as affected by salt treatment with special emphasis on phloem retranslocation and ion leaching, J Exp Bot 51 (2000) 1721-1732.

[62] H. Hayashi, M. Chino, Nitrate and other anions in the rice phloem sap, Plant Cell Physiol 26 (1985) 325-330.

[63] S.-C. Fan, C.-S. Lin, P.-K. Hsu, S.-H. Lin, Y.-F. Tsay, The Arabidopsis nitrate transporter NRT1.7, expressed in phloem, is responsible for sourre-to-sink remobilization of nitrate, Plant Cell 21 (2009) 27502761.

[64] C. Schobert, E. Komor, The differential transport of amino acids into the phloem of Ricinus conmunis L. seedlings as shown by the analysis of sieve-tube sap, Planta 177 (1989) 342-349. 
[65] S. Gattolin, H.J. Newbury, J.S. Bale, H.-M. Tseng, D.A. Barrett, J. Pritchard, A diumal component to the valiation in sieve tube amino acid content in wheat, Plant Physiol 147 (2008) 912-921.

[66] G. Lohaus, C. Moellers, Phloem transport of amino acids in two Brassica napus $\mathrm{L}$ genotypes and one $B$. carinata genotype in relation to their seed protein content, Planta 211 (2000) 833-840.

[67] J. Tilsner, N. Kassner, C. Struck, G. Lohaus, Amino acid contents and transport in oilseed rape (Brassica napus L.) under different nitrogen conditions, Planta 221 (2005) 328-338.

[68] C.A. Faria, F.L. Wackers, J. Pritchard, D.A. Barrett, T.C. Turlings, High susceptibility of bt maize to aphids enhances the performance of parasitoids of lepidopteran pests, PLoS One 2 (2007) e600.

[69] T.L Wilkinson, A.E. Douglas, Phloem amino acids and the host plant range of the polyphagous aphid, Aplis fabae, Entomol Exp Appl 106 (2003) 103-113.

[70] K.L. Ponder, ]. Pritchard, R. Harrington, J.S. Bale, Difficulties in location and acceptance of phloem sap combined with reduced concentration of phloem amino acids explain lowered performance of the aphid Rhopalosiphum padi on nitrogen deficient barley (Hordeun vulgare) seedlings, Entomol Exp Appl 97 (2000) 203-210.

[71] D.B. Fisher, P.K. Macnicol, Amino acid composition along the transport pathway during grain filling in wheat, Plant Physiol 82 (1986) 10191023.

[72] U. Jongebloed, J. Szederkenyi, K. Hartig, C. Schobert, E. Komor, Sequence of morphological and physiological events during natural ageing and senescence of a castor bean leaf: sieve tube occlusion and carbohydrate back-up precede chlorophyll degradation, Physiol Plant 120 (2004) 338-346.

[73] F. Bourgis, S. Roje, M.L Nuccio, D.B. Fisher, M.C. Tarczynski, C. Li, C. Herschbach. H. Rennenberg, M.J. Pimenta, T.-L. Shen, D.A. Gage, A.D. Hanson, S-methylmethionine plays a major role in phloem sulfur transport and is synthesized by a novel type of methyltransferase, Plant Cell 11 (1999) 1485-1498.

[74] F. Antognoni, S. Fornalè, C. Grimmer, E Komor, N. Bagni, Long-distance translocation of polyamines in phloem and xylem of Ricinus communis L. plants, Planta 204 (1998) 520-527.

[75] A.D. Peuke, M. Rokitta, U. Zimmermann, L. Schreiber, A. Haase, Simultaneous measurement of water flow velocity and solute transport in xylem and phloem of adult plants of Ricinus communis over a daily time course by nuclear magnetic resonance spectrometiy. Plant Cell Environ 24 (2001) 491-503.

[76] A. Lebaudy, A.-A. VĖry. H. Sentenac, K+ channel activity in plants: Genes, regulations and functions. FEBS Lett 581 (2007) 2357-2366.

[77] J. Fromm, S. Lautner, Electrical signals and their physiological significance in plants. Plant Cell Environ 30 (2007) 249-257.

[78] J. Pate, D. Arthur, $813 \mathrm{C}$ analysis of phloem sap carbon: novel means of evaluating seasonal water stress and interpreting carbon isotope signatures of foliage and trunk wood of Eucalyptus globulus, Decologia 117 (1998) 301-311.

[79] A.E. Douglas, S.J. Simpson, The nutritional physiology of aphids, Adv In Insect Phys, Academic Press, 2003, pp. 73-140.

[80] J. Takano, K. Miwa, T. Fujiwara, Boron transport mechanisms: collaboration of chamnels and transporters, Trends Plant Sci 13 (2008) 451457.

[81] V.R. Franceschi, N.M. Tarlyn, L-ascorbic acid is accumulated in source leaf phloem and transported to sink tissues in plants, Plant Physiol 130 (2002) 649-656.

[82] L. Tedone, R. Hancock, S. Alberino, S. Haupt, R. Viola, Long-distance transport of L-ascorbic acid in potato, BMC Plant Biology 4 (2004) 16.

[83] M. Knoblauch, W.S. Peters, K. Ehlers, A.J.E. van Bel, Reversible calciumregulated stopcocks in legume sieve tubes, Plant Cell 13 (2001) 12211230 .

[84] A.C. Furch, J.B. Hafke, A. Schulz, A.J. van Bel, $\mathrm{Ca}^{2+}$-mediated remote control of reversible sieve tube occlusion in Vicia faba, J Exp Bot 58 (2007) 2827-2838

[85] AC. Furch, AJ. van Bel, M.D. Fricker, H.H. Felle, M. Fuchs, J.B. Hafke, Sieve element $\mathrm{Ca}^{2+}$ channels as relay stations between remote stimuli and sieve tube occlusion in Vicia faba. Plant Cell 21 (2009) 21182132.

[86] M. Brauer, W.-J. Zhong, T. Jelitto, C. Schobelt, D. Sanders, E. Komor, Free calcium ion concentration in the sieve-tube sap of Ricinus conimunis L. seedlings, Planta 206 (1998) 103-107.

[87] G.G. Gould, C.G. Jones, P. Rifleman, A. Perez, J.S. Coleman, Variation in eastem cottonwood (Populis deltoides Bartr.) Phloem sap content caused by leaf development may affect feeding site selection behavior of the aphid, Chaitophorous populicola Thomas (Honoptera: Aphididae), Environ Entomol 36 (2007) 1212-1225.

[88] S. Chen, B.L. Petersen, C.E. Olsen, A. Schulz, B.A. Halkier; Long-distance phloem transport of glucosinolates in Arabidopsis, Plant Physiol 127 (2001) 194-201
[89] J. Christmann, W. Kreis, E. Reinhard, Uptake, transport and storage of cardenolides in foxglove. Cardenolide sinks and occurrence of cardenolides in the sieve tubes of Digitalis lanata, Bot Acta 106 (1993) 419427.

[90] E. Gowan, B.A. Lewis, R. Turgeon, Phloem transport of antirrhinaside, an indoid glycoside, in Asarina scandens (Scrophulariaceae). J Chem Ecol 21 (1995) 1781-1788.

[91] R Turgeon, R. Medville, Phloem loading. A reevaluation of the relationship between plasmodesmatal frequencies and loading strategies, Plant Physiol 136 (2004) 3795-3803.

[92] O.V. Voitselkhovskaja, O.A. Koroleva, D.R. Batashev, C. Knop, A.D. Tomos, Y.V. Gamalei, H.-W. Heldt, G. Lohaus, Phloem loading in two scrophulariaceae species. What can drive symplastic flow via plasmodesmata? Plant Physiol 140 (2006) 383-395.

[93] M. Wink, L. Witte, Turnover and transport of quinolizidine alkaloids. Diurnal fluctuations of lupanine in the phloem sap, leaves and fruits of Lupinus aibus L. Planta 161 (1984) 519-524.

[94] T. Hartmann, Chemical ecology of pyrrolizidine alkaloids, Planta 207 (1999) 483-495

[95] M.J. Lee, J.S. Pate, D.J. Harris, C.A. Atkins, Synthesis, transport and accumulation of quinolizidine alkaloids in Lupinus abus $L$. and $L$. angustifolius L. J Exp Bot 58 (2007) 935-946.

[96] A Givovich, J. Sandström, H.M. Niemeyer, J. Pettersson, Presence of a hydroxamic acid glucoside in wheat phloem sap, and its consequences for performance of Rhopalosiphum podi (L) (Homoptera: Aphididae). J Chem Ecol 20 (1994) 1923-1930.

[97] O. Fiehn. Metabolic networks of Cucurbita maxima phloem. Phytochemistry 62 (2003) 875-886.

[98] G.V. Hoad, Transport of hormones in the phloem of higher plants, Plant Glowth Regul 16 (1995) 173-182.

[99] JA.D. Zeevaart, Sites of abscisic acid synthesis and metabolism in Ricinus communis L. Plant Physiol 59 (1977) 788-791.

[100] ]. Allen, D. Baker, Free tryptophan and indole-3-acetic acid levels in the leaves and vascular pathways of Ricinus communis L. Planta 148 (1980) 69-74

[101] G.Y. Hoad, P. Gaskin, Abscisic acid and related compounds in phloem exudate of Yucca flaccida haw and coconut (Cocos nucifero L). Planta 150 (1980) 347-348.

[102] E. Komor, I. Liegl, C. Schobert, Loading and translocation of various cytokinins in the phloem and xylem of the seedlings of Ricinus communis L, Planta 191 (1993) 252-255.

[103] G.V. Hoad, JA. Retamales, R.J. Whiteside, M.J. Lewis, Phloem translocation of gibberellins in three species of higher plants, Plant Growth Regul 13 (1993) 85-88.

[104] V. Shulaev. J. Leon, I. Raskin, Is salicylic acid a translocated signal of systemic acquired resistance in tobacto? Plant Cell 7 (1995) 16911701.

[105] D.A. Morris, N.J. Larcombe, Phloem transport and conjugation of foliar-applied 1-aminocyclopropane-1-carboxylic acid in cotton (Gossypium hirsutum L). J Plant Physiol 146 (1995) 429-436.

[106] JS. Kamboj, P.S. Blake, D.A. Baker, Cytokinins in the vascular saps of Ricinus communis, Plant Growth Regul 25 (1998) 123-126.

[107] E. Madey, L. Nowack, J. Thompson, Isolation and characterization of lipid in phloem sap of canola, Planta 214 (2002) 625-634.

[108] F. Rocher, J.-F. Chollet, C. Jousse, J.-L. Bonnemain, Salicylic acid, an ambimobile molecule exhibiting a high ability to accumulate in the phloem, Plant Physiol 141 (2006) 1684-1693.

[109] W Truman, M.H. Bennett, I. Kubigsteltig. C. Tumbull, M. Grant, Arabidopsis systemic immunity uses conserved defense signaling pathways and is mediated by jasmonates, Proc Natl Acad Sci U S A 104 (2007) 1075-1080.

[110] T. Chhun, Y. Uno, S. Taketa, T. Azuma, M. Ichii, T. Okamoto, S. Tsurumi, Saturated humidicy accelerates lateral root development in rice (Oryza sativa L.) seedlings by increasing phloem-based auxin transport, J Exp Bot 58 (2007) 1695-1704.

[111] C. Jager, G. Symons, N. Glancy, J. Reid, J. Ross, Evidence that the mature leaves contribute auxin to the immature tissues of pea (Pisum sotivum L). Planta 226 (2007) 361-368.

[112] HS. Robert, J. Friml, Auxin and other signals on the move in plants, Nat Chem Biol 5 (2009) 325-332.

[113] F. Gaupels, A.C. Furch, T. Will, L.A. Mur, K.H. Kogel, A.J. van Bel, Nitric oxide generation in Vicia faba phloem cells reveals them to be sensitive detectors as well as possible systemic transducers of stress signals, New Phytol 178 (2008) 634-646.

[114] H.W. Jung, T.J. Tschaplinski, L. Wang, J. Glazebrook, J.T. Greenberg. Priming in systemic plant immunity, Science 324 (2009) 89-91

[115] A. Lehrer, D. Dugassa-Gobena, S. Vidal, K. Seifert, Transport of resistance-inducing sterols in phloem sap of barley, Z Naturforsch C 55 (2000) $948-952$. 
[116] S. Lalonde, M. Tegeder, M. Throne-Holst, W.B. Frommer, JW. Patrick Phloem loading and unloading of sugars and amino acids, Plant Cell Environ 26 (2003) 37-56.

[1]7] C.W. Windt, F.J. Vergeldt, P.A.D. Jager, H. Van As, MRI of long-distance water transport: a comparison of the phloem and xylem flow characteristics and dynamics in poplar, castor bean, tomato and tobacco, Plant Cell Environ 29 (2006) 1715-1729.

[118] J.S Pate, C.A. Atkins, K. Hamel, D.L. McNeil, D.B. Layzell, Transport of organic solutes in phloem and xylem of a nodulated legume. Plant Physiol 63 (1979) 1082-1088.

[119] D.E. Mitchell, M.V. Gadus, M.A. Madore, Patterns of assimilate production and translocation in muskmelon (Cucumis melo L. ): I. Diurnal patterns, Plant Physiol 99 (1992) 959-965.

[120] H. Winter, G. Lohaus, H.W. Heldt, Phloem transport of amino acids in relation to their cytosolic levels in Barley leaves, Plant Physiol 99 (1992) 996-1004.

[121] C. Grimmer, E. Komor, Assimilate export by leaves of Ricinus communis L. growing under normal and elevated carbon dioxide concentrations: the same rate during the day, a diferent rate at night, Planta 209 (1999) 275-281.

[122] J Kehr, F. Hustiak, C. Walz, L. Willmitzer, J. Fisahn, Transgenic plants changed in calbon allocation pattern display a shift in diurnal growth pattem, Plant J 16 (1998) 497-503.

[123] L. Corbesier, A. Havelange, P. Lejeune, G. Bemier, C. Périlleux, N content of phloem and xylem exudates during the transition to flowering in Sinapis aiba and Arabidopsis thatiana, Plant Cell Environ 24 (2001) 367-375.

[124] J.S. Pate, C.A. Atkins, Xylem and phloem transport and the functional economy of carbon and nitrogen of a legume leaf. Plant Physiol 71 (1983) 835-840.

[125] L. Corbesier, G. Bernier, C. Perilleux, C: N ratio increases in the phloem sap during floral transition of the long-day plants Sinapis alba and Arabidopsis thaliana, Plant Cell Physiol 43 (2002) 684-688.

[126] D.E. Mitchell, MA. Madore, Patterns of assimilate production and translocation in muskmelon (Cucumis melo L.): II. Low Temperature Effects, Plant Physiol 99 (1992) 966-971.

[127] P.]. Hocking. The composition of phloem exudate and xylem sap fiom tree tobacco (Nicotiana glauca Grah), Ann Bot 45 (1980) 633-643.

[128] J.P. Despeghel, Étude des mécanismes de l'absorption des acides aminés neutres par les tissus foliaires et de leur accumulation dans les nervures, Thèse $3^{\mathrm{e}}$ cycle, université de Poitiers, 1981, pp. 121.

[129] D. Rentsch, B. Hirner, E. Schmelzer, W.B. Frommer, Salt stress-induced proline transporters and salt stress-repressed broad specificiry amino acid permeases identified by suppression of a yeast amino acid permease-targeting mutant, Plant Cell 8 (1996) 1437-1446.

[130] E.A. Bray, Plant responses to water deficit, Trends Plant Sci $2(1997)$ $48-54$

[131] E.S. Ober, R.E. Sharp. Proline accumulation in maize (Zeo mays L.) primary roots at low water potentials I. Requirement for increased levels of abscisic acid. Plant Physiol 105 (1994) 981-987.

[132] J. Sandström, A. Telang, N.A. Moran, Nutritional enhancement of host plants by aphids - a comparison of three aphid species on grasses. J Insect Physiol 46 (2000) 33-40.

[133] A. Telanz, J. Sandström, E. Dyreson, N.A. Moran, Feeding damage by Diuraphis naxia results in a nutritionally enhanced phloem diet. Entomol Exp Appl 91 (1999) 403-412.

[134] G. Febvay, J. Bonnin, Y. Rahbé, R. Bournoville, S. Delrot, J.L Bonnemain, Resistance of different lucerne cultivars to the pea aphid Acyrthosiphon pistum: influence of phloem compasition on aphid fecundity. Entomol Exp Appl 48 (1988) 127-134.

[135] A.J. Karley, A.E. Douglas, W.E. Parker, Amino acid composition and nutritional quality of potato leaf phloem sap for aphids, J Exp Biol 205 (2002) 3009-3018.

[136] A.E. Douglas, Phloem-sap feeding by animals: problems and solutions, J Exp Bot 57 (2006) 747-754.

[137] Y. Rahbé, G. Febvay, B. Delobel, R. Bournoville, Acyrthosiphon pistun performance in response to the sugar and amino acid composition of artificial diets, and its relation to lucerne varietal resistance, Entomol Exp Appl 48 (1988) 283-292.

[138] T.E Mittler, R.H. Dadd, Gustatoly discrimination between liquids by the aphid Myzus persicae (Sulzer), Entomol Exp Appl 7 (1964) 315328.

[139] J.L. Auclair, Feeding and nutrition of the ped aphid Acyrthosiphor pisum (Homoptera: Aphididae) on chemically defined diets of various $\mathrm{pH}$ and nutrient levels, Ann Entomol Soc Am 58 (1965) 855-875

[140] W.F. Tjallingii, Salivary secretions by aphids interacting with proteins of phloem wound responses, J Exp Bot 57 (2006) 739-745.

[141] D. Rentsch, 5. Schmidt. M. Tegeder, Transporters for uptake and allocation of organic nitrogen compounds in plants, FEBS Lett 581 (2007) 2281-2289.
[142] L. Chen, A. Ortiz-Lopez, A Jung, D.R. Bush, ANT1, an aromatic and neutral amino acid transpolter in Arabidopsis, Plant Physiol 125 (2001) 1813-1820.

[143] J Sandstrōm, N. Moran, How nutritionally imbalanced is phloem sap for aphids? Entomol Exp Appl 91 (1999) 203-210.

[144] N.A. Moran, H.E. Dunbar, J.L. Wilcox, Regulation of transcription in a reduced bacterial genome: nutrient-provisioning genes of the obligate symbiont Buchnera aphidicola, J Bacteriol 187 (2005) 4229-4237.

[145] E.A. Gündüz, A.E. Douglas, Symbiotic bacteria enable insect to use nutritionally inadequate diet, Proc R Soc Lond B Biol Sci 276 (2009) 987-991.

[146] C. Schobert, P. Gloßmann, M. Gottschalk, E. Komor, A. Pecsvaradi, U.Z. Mieden, Sieve-tube exudate from Ricinus commmis L seedlings contains ubiquitin and chaperones. Plantd 196 (1995) 205-210.

[147] S. Balachandran, Y. Xiang, C. Schobert, G.A. Thompson, WJ. Lucas, Phloem sap proteins from Cucurbita maxina and Ricinus conmunis have the capaciry to traffic cell to cell through plasmodesmata. Proc Natl Acad Sci U S A 94 (1997) 14150-14155.

[148] C. Schobert, L. Baker, J. Szederkényi, P. Gloßmann. E. Komor, H. Hayashi, M. Chino, WJ. Lucas, Identification of immunologically related proteins in sieve-tube exudate collected from monocotyledonous and dicotyledonous plants, Planta 206 (1998) 245-252.

[149] C. Walz, P. Giavalisto, M. Schad, M. Juenger, J. Klose, J. Kehr, Proteomics of curcurbit phloem exudate reveals a network of defence proteins, Phytochemistry 65 (2004) 1795-1804

[150] P. Giavalisco, K. Kapitza, A. Kolasa, A. Buhtz, J. Kehr, Towards the proteome of Brassica napus phloem sap. Proteomics 6(2006) 896-909.

[151] R. Stadler, K.M. Wright, C. Lautertach, G. Amon, M. Gahrtz, A. Feuerstein, K.J. Oparka, N. Sauer, Expression of GFP-fusions in Arabidopsis companion cells reveals non-specific protein trafficking into sieve elements and identifies a novel post-phloem domain in roots, Plant J 41 (2005) 319-331.

[152] L. Corbesier, C. Vincent, S. Jang, F. Fomara, Q. Fan, I. Searle, A Giakountis, S. Farrona, L. Gissot, C. Tumbull, G. Coupland, FT protein movement contributes to long-distance signaling in floral induction of Arabidopsis, Science 316 (2007) 1030-1033.

[153] A.K. Banerjee, M. Chatterjee, Y. Yu, S.G. Suh, W.A. Miller, D.J. Hannapel. Dynamics of a mobile RNA of potato involved in a long-distance signaling pathway, Plant Cell 18 (2006) 3443-3457

[154] H. Hayashi, A. Fukuda, N. Suzui, S. Fujimaki, Froteins in the sieve element-companion cell complexes: their detection, localization and passible functions, Funct Plant Biol 27 (2000) 489-496.

[155] ᄃ Walz, M. Juenger, M. Schad, J. Kehr, Evidence for the presence and activity of a complete antioxidant defence system in mature sieve tubes, Plant J 31 (2002) 189-197.

[156] A. Bames, J. Bale, C. Constantinidou, P. Ashton, A. Jones, J. Pritchard Determining protein identity from sieve element sap in Ricinus communis L. by quadrupole time of flight (Q-TOF) mass spectrometry. Exp Bot 55 (2004) 1473-1481.

[157] M.K. Lin, Y.J. Lee, T.J. Lough, B.S. Phinney. WJ. Lucas, Analysis of the pumpkin phloem proteome provides insights into angiosperm sieve tube function. Mol Cell Proteornics 8 (2009) 343-356.

[158] J. Kehr. Phloem sap proteins: their identities and potential roles in the interaction between plants and phloem-feeding insects, J Exp Bot 57 (2006) 767-774.

[159] Y. Ishiwatari, C. Honda, I. Kawashima, S.-I. Nakamura, H. Hirano, S. Mori, T. Fujiwara, H. Hayashi, M. Chino. Thioredoxin $\mathrm{H}$ is one of the major proteins in rice phloem sap, Planta 195 (1995) 456-463.

[160] Y. Ishiwatari, T. Fujiwara, K.C. McFarland, K. Nemoto, H. Hayashi, M. Chino, W.J. Lucas, Rice phloem thioredoxin $\mathrm{h}$ has the capaciry to mediate its own cell-to-cell transport through plasmodesmata, Planta 205 (1998) 12-22.

[161] A Graig. R. Ewan, J. Mesmar, V. Gudipati, A. Sadanandom, E3 ubiquitin ligases and plant innate immunity, J Exp Bot 60 (2009) 1123-1132.

[162] R.D. Vierstra, The ubiquitin-265 ploteasome system at the nexus of plant biology, Nat Rev Mol Cell Biol 10 (2009) 385-397.

[163] A. Imlau, E. Truemit, N. Sauer, Cell-to-cell and long-distance trafficking of the green fluorescent protein in the phloem and symplastic unloading of the protein into sink tissues, Plant Cell 11 (1999) 309-322.

[164] K. Aoki, N. Suzui, S. Fujimaki, N. Dohmae, K. Yonekurd-Sakakibara, T. Fujiwara, H. Hayashi, T. Yamaya, H. Sakakibara, Destination-selective long-distance movement of phloem proteins, Plant Cell 17 (2005) 1801-1814.

[165] S. Fujimaki, T. Fujiwara, H. Hayashi, A new method for direct introduction of chemicals into a single sieve tube of intact rice plants, Plant Cell Physiol 41 (2000) 124-128.

[166] B.K. Ham, J.L. Brandom, B. Xoconostle-Cazares, V. Ringgold, T.J. Lough W.J. Lucas, A polypyrimidine tract binding protein, pumpkin RBP50, forms the basis of a phloem-mobile ribonucleoprotein complex, Plant Cell 21 (2009) 197-215. 
[167] J Kehr, A. Buhtz, Long-distance transport and movement of RNA thiough the phloem, J Exp Bot 59 (2008) 85-92.

[168] J. Kehr, Long-distance transport of macromolecules through the phloem, F1000 Biology Repolts 1 (2009) 131.

[169] C. Doering-Saad, H.]. Newbury, C.E. Couldridge, J.S. Bale, J. Pritchard, A phloem-enriched cDNA library from Ricinus: insights into phloem function, J Exp Bot 57 (2006) 3183-3193.

[170] A. Omid, T. Keilin, A. Glass, D. Leshkowitz, S. Wolf, Characterization of phloem-sap transcription profile in melon plants, J Exp Bot 58 (2007) $3645-3656$.

[171] R. Le Hir, J. Beneteau, C. Bellini, F. Vilaine, S. Dinant, Gene expression profiling: keys for investigating phloem functions, Trends Plant Sci 13 (2008) 273-280.

|172| R. Deeken, P. Ache, I. Kajahn, J. Klinkenberg, G. Bringmamn, R. Hedrich, Identification of Arabidopsis thaliana phloem RNAs provides a search criterion for phloem-based transcripts hidden in complex datasets of microarray experiments, Plant J 55 (2008) 746-759.

[173] B.C. Yoo, F. Kragler, E. Varkonyi-Gasic, V. Haywood, S. Archer-Evans, Y.M. Lee, T.J. Lough, W.J. Lucas, A systemic small RNA signaling system in plants, Plant Cell 16 (2004) 1979-2000.

[174] A. Buhtz, F. Springer, L. Chappell, D.C. Baulcombe, J. Kehr, Identification and characterization of small RNAs from the phloem of Brassica napus, Plant J 53 (2008) 739-749.

[175] B.D. Pant, M. Musialak-Lange, P. Nuc, P. May, A. Buhtz, J. Kehr, D. Walther, W.R. Scheible, Identification of mutrient-responsive Arabidopsis and rapeseed microRNAs by comprehensive real-time polymerase chain reaction profiling and small RNA sequencing. Plant Physiol 150 (2009) 1541-1555.

|176| K. Kalantidis, H.T. Schumacher, T. Alexiadis, J.M. Helm, RNA silencing movement in plants, Biol Cell 100 (2008) 13-26.

[177] 0 . Voinnet, Origin, biogenesis, and activity of plant microRNAs, Cell $136(2009) 669-687$.
[178] B.D Pant, A. Buhtz, J. Kehr, W.R. Scheible, MicroRNA399 is a longdistance signal for the regulation of plant phosphate homeostasis, Plant J 53 (2008) 731-738.

[179] S. Zhang, L. Sun, F. Kragler, The phloem-delivered RNA pool contains small noncoding RNAs and interferes with translation, Plant Physiol 150 (2009) 378-387.

[180] J.K. Roney, P.A. Khatibi, J.H. Westwood, Cross-species translocation of mRNA from host plants into the parasitic plant dodder, Plant Physiol 143 (2007) $1037-1043$

[181] R. David-Schwartz, S. Runo, B. Townsley, J. Machuka, N. Sinha, Longdistance transport of mRNA via parenchyma cells and phloem across the host/parasite junction in Cuscuta, New Phytol 179 (2008) 11331141.

[182] J.A. Baum, T. Bogaert, W. Clinton, G.R. Heck, P. Feldmann, O. Ilagan, S. Johnson, G. Plaetinck, T. Munyikwa, M. Pleau, T. Vaughn, J. Roberts, Control of coleopteran insect pests through RNA interference, Nat Biotech 25 (2007) 1322-1326.

[183] Y.-B. Mao, W.-J. Cai, J.-W. Wang, G.-J. Hong, X.-Y. Tao, L.-J. Wang, Y.-P. Huang, $X$. $-Y$. Chen, Silencing a cotton bollworm $P 450$ monooxygenase gene by plant-mediated RNAi impairs larval tolerance of gossypol, Nat Biotech 25 (2007) 1307-1313.

[184] G.A. Thompson, F.L. Goggin. Transcriptomics and functional genomics of plant defence induction by phloem-feeding insects, J Exp Bot 57 (2006) 755-766.

[185] V. Pegadaraju, J. Louis, V. Singh, J.C. Reese, J. Bautor, B.J. Feys, G. Cook, J.E. Parker, J. Shah, Phloem-based resistance to green peach aphid is controlled by Arabidopsis PHYTOALEXIN DEFICIENT4 without its signaling partner ENHANCED DISEASE SUSCEPTIBILTTY1, Plant J 52 (2007) 332-341.

[186] T. Will, W.F. Tjallingii, A. Thonnessen, A.J. van Bel, Molecular sabotage of plant defense by aphid saliva, Proc Natl Acad Sci U S A 104 (2007) 10536-10541. 